\title{
Monetary Policy and Money Supply in Nigeria: A Comparative Analysis: 1993-2018
}

\author{
Abdurrauf Babalola (PhD) \\ Department of Economics, Al-Hikmah University, Ilorin, Nigeria. \\ Abdulkareem Ogirima \\ Deputy Director, Galaxy Uniprep Centre, Wuse II, Abuja, Nigeria
}

\begin{abstract}
The study researched on a comparative analysis of the impact of monetary policy on money stock in Nigeria. Monthly data were sourced from the CBN online database between 1993M1 and 2018M10. Monetary policy rate (MR), cash reserve ratio (CR) and liquidity ratio (LR) represented the main monetary policy instruments that were made the explanatory variables while broad money supply (M2) stood as dependent variable. ADF and PP tests were carried out to make the data stationary and then VAR and ECM were employed for analysis. Standardised coefficient through the ARDL was also used for proper comparison. Finding of the study revealed that, in the short run, all the variables had the correct negative signs but only the CR was significant, while in the long run, all variables were correctly signed and significant except for CR. Also, monetary policy had a high speed of adjusting the money stock back to equilibrium. The result also unveiled that, LR had the greatest impact in regulating money stock, followed by $\mathrm{CR}$ and the MR. However, MR had the highest ability to forecast money stock, followed by LR and then CR, and the abilities were felt even up to the eight month. The study, therefore recommends that the monetary authority should give most attention to LR in regulating money stock in Nigeria and mostly consider MR in forecasting the stock of money.
\end{abstract}

JEL Codes: E52, E58

DOI: $10.7176 / \mathrm{PPAR} / 9-3-12$

Publication date:March $31^{\text {st }} 2019$

\section{Introduction}

The effect of monetary policy in regulating quantity of money in circulation which affects the liquid nature of the economy is paramount in the operations of the monetary authority, which in Nigeria, is the Central Bank of Nigeria (CBN). Stock of money in circulation will determine the price level of an economy - inflation level. Just as confidence in the price level of any society will dictate to what extent businessmen would be able to forecast business future. When the general price level is stable, predictions and precisions are possible and this will go a long way in attracting investment within the shores of the economy. Thus, there is need to regulate growth in money supply by the monetary authority.

The monetary authority uses monetary policy, through its instruments, to regulate growth in money supply in order to achieve a predetermined ultimate goal. The essence of this study is majorly to compare the frequently used instruments of monetary policy as it impacts on money supply regulation in the Nigerian economy, that is, which instrument is most effective in regulating growth of money supply and the period of effect. In line with this, the study shall investigate the short run and long run impact of monetary policy instruments on money supply growth and to verify if the speed of adjustment of money supply back to equilibrium is slow or fast with changes in monetary policy in Nigeria.

Money supply is so important in any economy in the world today as money is used in most economies, therefore, it has enormous impact on economic activity like investment which is affected by money supply through changes in interest rate (lending rate) that spur or rein investment. Increase in the money in people's hand will motivate/purr, kindle spending and cause improvement in aggregate demand which will in turn stimulate investment in both the real and financial sectors. When the economy is in boom, through rise in money supply, prices of stock market will rise and firms will issue debt and equity to raise fund for their businesses and expand and therefore request for more labour (employment). However, this expansion in money stock may lead to inflation if it continues. As such, lenders request for more interest rates due to reduction in the purchasing power of money during this period. In Nigeria, the quantity of money affects the possibility of commercial banks to create more monies through giving loans and advances to investors. The tightening and easing policies of the Central Bank of Nigeria (CBN) are mostly used to manage money stock in the economy. Tightening/easing policy would mean that the CBN contracts/expands the ability of banks to create new money in their coffers which has multiplier effect on the economy. With easing policy, investors get new loans for business expansion, which increases the level of activity and total output in the system. This will improve the level of employment as more labour will be required to carry out the expansion exercise in investment and it will also affect the level of prices since more money is available for purchasing goods. These policies could be carried out through a number 
of active instruments such as the monetary policy rate (MR) which affects three rates in the Nigerian economy: the prime lending rate; treasury bill rate in the open market operation; and the interbank rate. Others are cash reserve ratio $(\mathrm{CR})$, liquidity ratio and the discount window.

As to what determines supply of money in an economy, the monetary policy of central bank is the most important determinant through its instruments to either expand or contract the stock of money in the economy. Central banks regulate the money supply by regulating the most important component of money supply which is the bank deposit which central banks have appreciable quantity of control over. With deposit in commercial banks, central bank requires commercial banks to keep, as reserve, a part of demand deposit for owners to withdraw at will and a fraction to be deposited with the central bank. It controls reserves by lending money to commercial banks and changing the discount rate- monetary policy rate (MR).

Questions have been raised on whether or not the monetary authority (CBN in Nigeria) has significant influence on money supply in an economy. Which of the policy instruments should be used most as it has the most prominent impact on money supply? Are the conventional instruments used by the CBN effective? Could there be any short run or long run impact of these instruments on money supply? What is the speed of adjustment, low or high? These are the questions this study will unveil, and which are yet to be given much attention in economic literature in Nigeria. Few investigations by researchers showed assorted results and imprecision probably due to data disparity and methods used.

\section{Stylised Facts about Money Supply and Monetary Policy in Nigeria (1990-2018).}

Monetary policy is a tool of general macroeconomic management, designed by monetary authorities to achieve government economic objectives. It aims at achieving certain national goals which have historically included full employment (low unemployment rate), high output (high output growth), a stable price level (low inflation rate), and a stable exchange rate (desirable balance of payments) positions. They are often referred to as the "ultimate goals" of monetary policy (CBN 2014). These goals are usually achieved indirectly by the monetary authorities (central banks) through its use of monetary policy instruments. On monetary policy in Nigeria, the recent policy instruments used are Monetary Policy Rate (MR) formally Minimum Rediscount Rate, and other intervention instruments such as Open Market Operation (OMO), Discount Window Operation, Cash Reserve Ratio (CR), Liquidity Ratio (LR) and Foreign Exchange Net Open Position (NOP) limit (CBN 2014).

Before the 1986 structural adjustment programme (SAP) and the subsequent financial sector reforms of 1987, the conduct of monetary policy was directly regulated by the CBN. In Nigeria, the Central Bank conducts monetary policy primarily to achieve price stability using monetary policy rate (MR) as a prime instrument that signals the direction of interest rates as nominal anchor (CBN, 2013). The MPR, which replaced the Minimum Rediscount Rate (MRR) in December 2006, serves as an indicative rate for transactions in the inter-bank money market as well as other interest rates in the money market transactions. The MRR was replaced because of its inability to control supply settlement balances of banks and motivate the banking system to target zero balances at the CBN through an active interbank trading or transfer of balances at the bank (Soludo 2008). The MRR represented the minimum interest rate banks can borrow from the CBN while the MPR is a short term interest rate at which banks can predictably borrow from the CBN.

In order to manage the quantity of money in circulation, the $\mathrm{CBN}$ uses monetary easing and tightening policies as means of expanding and contracting the quantity of money in the economy using its said instruments. In 2002, monetary policy implementation was faced with some challenges as the problem of excess liquidity persisted from previous year, capital flight and the demand pressure in the foreign exchange market intensified. In order to encourage banks to reduce interest rate on lending to encourage investment and employment, the Minimum Rediscount Rate (MRR) was reviewed downward from 19 per cent in 1999 to 13.5 in 2000 which was also accompanied with moral suasion. These developments led to a fall in bank deposit and lending rate, particularly during the second half of 2002 which reduced the money stock by about $7 \%$ as depicted in figure 1 .

In the wake of the global financial crisis in 2008 when money supply was so low, the bank largely adopted the policy of monetary easing to address the problem of liquidity shortages in the banking system from September 2008 to September 2010. The monetary policy easing measures taken during the period included: Stoppage of aggressive liquidity mop-up since September 18, 
$\%$ Change M2

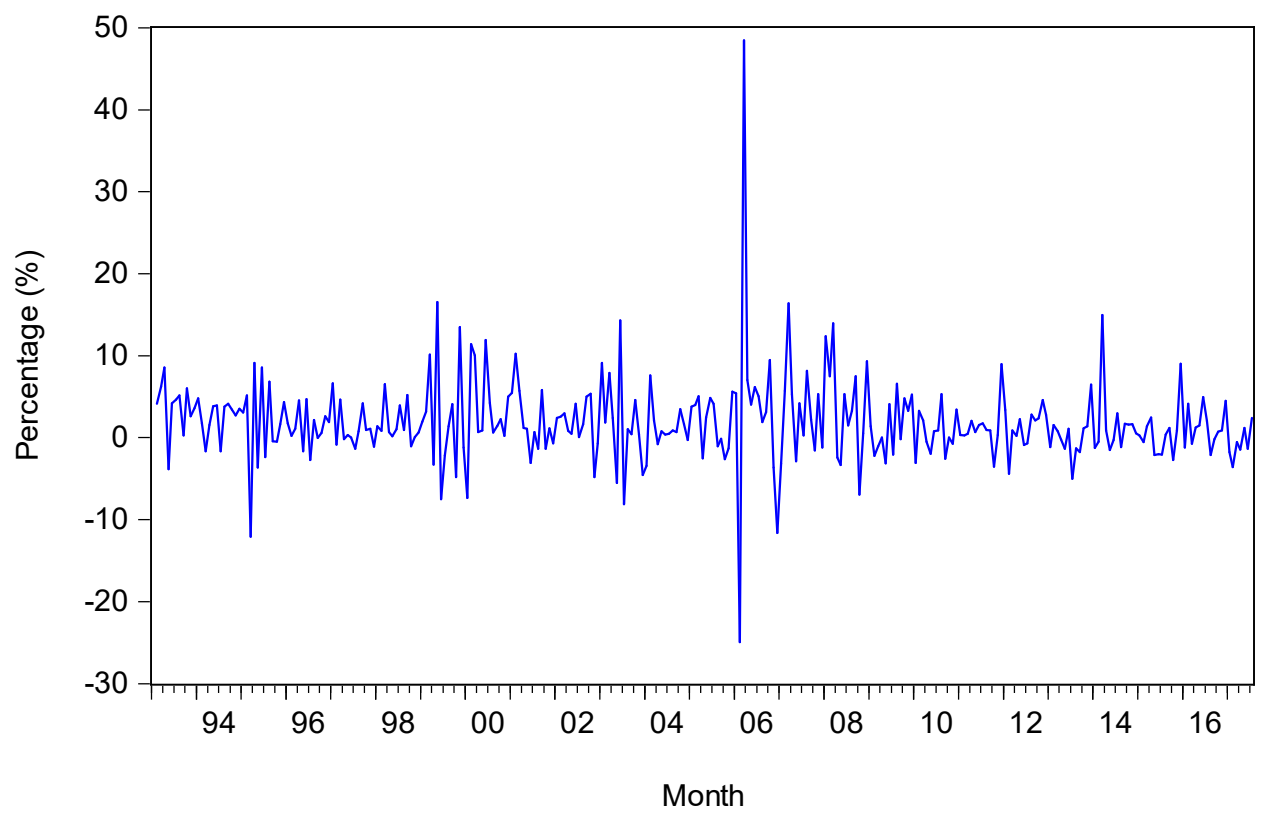

Figure 1: Trend in Money Supply growth.

2008; Continuous reduction of monetary policy rate (MR) from 10.25 to 6.0 per cent; Reduction of cash reserve requirement (CR) from 4.0 to 2.0 and 1.0 per cent; Reduction of liquidity ratio (LR) from 40.0 to 30.0 , and 25.0 per cent, among others (CBN 2011).

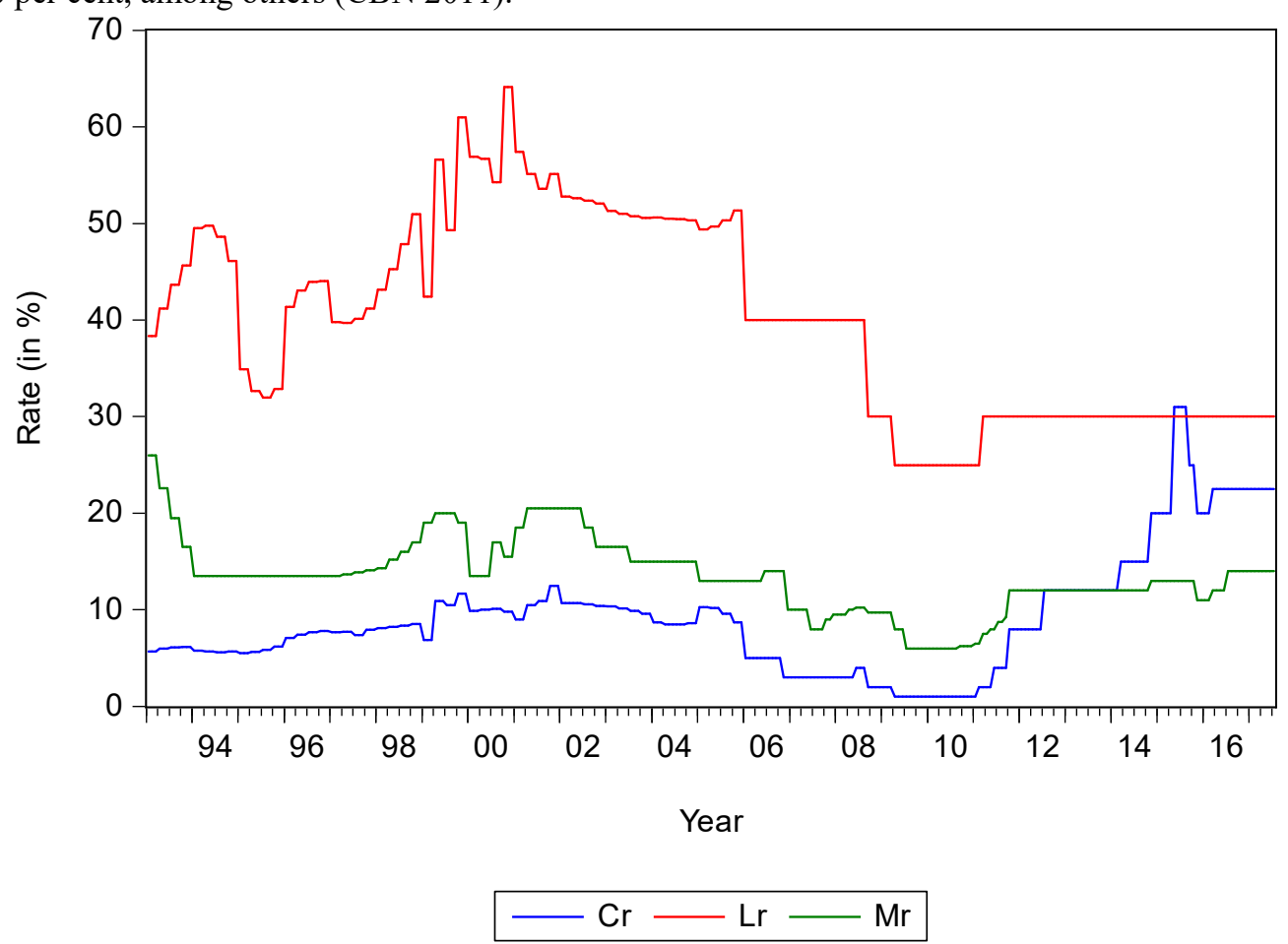

Figure 2: Trend of Monetary Policy Instruments

The Monetary policy measures of 2003 were planned to combine the gains of 2002 by supporting real sector activities, while keeping liquidity and exchange rate policies market determined. Broad money (M2) in this year grew by 24.1 per cent instead of 15.0 per cent targeted which was basically due to policy easing as monetary policy instruments (MR, CR and LR) dropped as shown in figure 2.

Monetary policy during the period 2012 focused on deploying the mix of appropriate instruments to deliver on price stability. The Bank continued with its tight monetary policy stance, which commenced in the third quarter of 2010, using the Monetary Policy Rate (MR) as the signaling interest rate to affect money supply and cut back inflation expectations (CBN 2012). 
All through the years up to 2018 and even beyond, the CBN has been using, as paramount monetary policy instruments, monetary policy rate, cash reserve ratio and the liquidity ratio, to regulate the money stock in the economy. This is evident in the statement of the Monetary Policy Committee of the CBN in 2019, as members agreed to maintain the monetary policy stance of constant Monetary Policy Rate of $14 \%$, Cash Reserve Ratio of $22.5 \%$ and Liquidity Ratio of $30 \%$ and then the Asymmetric Window put between +200 and -500 basis point around the monetary policy rate (Onuba, 2019).

\section{A Review of Supporting Literature}

Starting with theoretical issues, the Classical economist felt it was important to control the growth of money as forecasted by the quantity theory of money. It postulated policies which might manage the quantity supply of money among which are interest rate control, monetary base control and open market operations. This quantity theory was challenged by Keynesian economists that money supply is unaffected by interest rates. The quantity theory was given prominence and invigorated by the monetarists. The mainstream economists are in tandem that the quantity theory of money supply holds true in the long run but in the short run, money velocity is not stable. There are basically two views of determination of the stock of money. The first is that money supply is exogenously determined by the central bank. The second view remains that money stock is endogenously determined by changes in economic activity which affects people's desire to hold currency related to deposit and rate of interest among others.

The framework for this study is not different from that used by Meltzer (1995) in his study on the French money supply and still in line with the study of Friedman and Schwartz (1963) on the History of U.S. money supply. They posited that high-powered money which consists of currency held by the public and demand deposit in bank is very paramount in any study of money supply. Accordingly, high-powered money is issued and regulated by the government through the central bank as obtainable in the Nigerian economy and most economies of the world. The narrow definition of money (M1) is also referred to as high-powered money, sometimes called monetary base. Preference is given to the broad definition by Friedman (2006) and many other monetarists as currency (c), demand deposit and time deposits. Money supply is also determined by the money multiplier which is not constant. According to the study of Meigs and Wolman (1971), the way banks (demand deposit) and public (currency) use the available supply of high-powered money determine the size of the money multiplier which is the ratio of total money supply to high-powered money. Crucial ratios on this are the ratio of currency to total money held by public and the ratio of reserves to deposits held by banks. Thus, the volume of high-powered money, the currency-money ratio and the reserve-deposit ratio would determine changes in money supply. Cagan (1969) study showed that changes in high-powered dominate the long-term movement of money stock. Brunner and Meltzer submitted a more controversial stand that changes in high-powered money also dominate short run movement in the quantity of money supply. In the words of Meigs and Wolman (1971), "empirical studies of relations between the monetary base and the total money supply establish a strong basis for believing that central banks can control the money supply. However there are two possible reasons why they do not. The first is that the results produced by statistical and logical analysis of past data establish that when a central bank actually tries to control the money supply, those relationships which theory and empirical analysis suggest are stable turn out to be operationally unstable. This of course, means that a central bank that sets out to control the money supply would find out that it cannot. The second reason is simply because they do not want to" (Meigs and Wolman $1971 \mathrm{pg}$. 23). Some monetarists are of the opinion that availability of credit is more active in controlling and regulating money supply than the interest rates since it is possible to control spending by restricting the bank reserves availability without adjusting the interest rates. However there is need for empirical evidence for the Nigerian economy.

Bakare (2011) examined the money supply growth determinants in Nigeria employing a quasiexperimental research design approach for data analysis. The study revealed that credit expansion to private individuals and firms contributed to the growth in money supply in Nigeria.

Abakpai et al (2018) also carried out a research on determinants of money supply in Nigeria between 1981 and 2015. They employed six variables as their explanatory variables which include interest rate and exchange and then used ARDL and ECM models to analyse the time series data. Their findings showed that interest rate and exchange rate have relationship with money supply in Nigeria.

Previous empirical studies were conducted by researchers on monetary policy and money supply among whom are Tobin (1953); Friedman and Schwartz (1963); Meigs and Wolman (1971); Mishkin (1995, 2007); Ali and Islam (2010); However, study of impact of monetary policy on money supply is quite scanty for the Nigerian economy.

\section{Methodology}

In order to investigate the efficacy of monetary policy on money supply in Nigeria, the work uses a vector autoregression (VAR) model. Data is firstly tested for stationarity by means of the Augmented-Dickey Fuller 
(ADF) and the Phillip Peron (PP) tests. Then, cointegration technique is employed to test for cointegration, after which an error correction model (ECM) is used to estimate the short and long run equation and the existence of error correction. Along the line, we employ Scaled Coefficient of ARDL to compare the variables. Residual checks are also carried out to test for heteroskedasticity (White test) and serial correlation (Lagrange Multiplier). Finally, forecasted variance decomposition is performed to respectively scrutinize the forecasting variance ability of monetary policy instruments on quantity of money stock in Nigeria, i.e. the percentage of forecast error variance in money supply that is explained by its innovations and those of the monetary policy aggregates. Stability checks are carried out as well. All the variables in the data set are first transformed into the natural logarithm for obvious statistical reasons of standardization, equalisation of the variables and removal of trend as rightly said by Mobolaji and Oluwatoyi (2012).

Muhammad Mahboob Ali and Anisul M. Islam (2010). Money Supply Function for Bangladesh: An Empirical Analysis. AIUB Bus Econ Working Paper Series, No 2010-01, http://orp.aiub.edu/abewps-201

\section{Model Specification}

The study adapted the models of Meigs and Wolman (1971) as further modified and put into linear function by Ali and Islam (2010) who made broad money supply as a function of money multiplier and reserve money and then made money multiplier as a function of currency-deposit ratio; reserve-deposit ratio; and excess-deposit ratio. The model for this study is therefore modified to test for the impact of monetary policy instruments on money stock in Nigeria. Broad money supply (M2) is modeled as a function of monetary policy variables monetary policy rate (MR), cash reserve deposit ratio (CR) and liquidity ratio (LR). This is expressed as

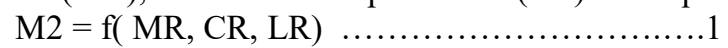

translating equation 1 into an econometric model, we obtain

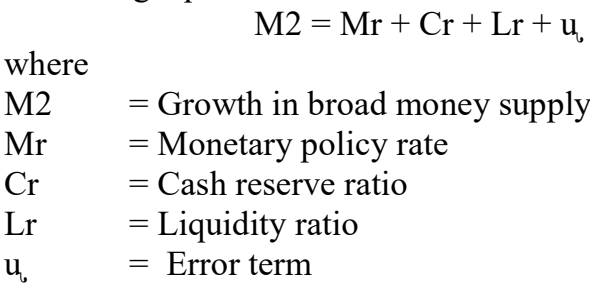

It is expected (a priori expectation), following the above specification of equation 2 , that smaller required reserve ratio $(\mathrm{Cr})$, which is the ratio of required reserves to the total deposits of the bank $\left(\mathrm{r}_{\mathbf{r}}=\mathrm{RR} / \mathrm{D}\right)$, enables greater expansion in the credit by the banks and thus increases the money supply. The $\mathrm{Cr}$ ratio is legally fixed by the central bank.

Interest rate (MR) has a positive effect on the money multiplier and hence on the money supply. A rise in the $\mathrm{MR}$ will reduce the reserve ratio $(\mathrm{R} 2)$, which raises the money multiplier $(\mathrm{m})$ and hence reduces the money supply (M2). Same thing applies to LR.

The study covers the period between 1993M1 and 2018M10 which amount to 310 observations. Data set is gotten from the CBN database assessed in January 2019. However, monthly data for MR, CR, and LR were not available for the periods 1993-2002/5. The available quarterly data were transformed to monthly in order to suit the frequency of this study.

The study throws its weight on the statement of Nkoro and Uko (2016) which says "although ARDL cointegration technique does not require pre-testing for unit roots, to avoid ARDL model crash in the presence of integrated stochastic trend of I(2), we are of the view the unit root test should be carried out to know the number of unit roots in the series under consideration". Therefore we present the result of only Augmented-Dickey Fuller (ADF) and Phillip Peron (PP) tests of unit root in Table 1.

\section{Main Findings \\ Unit Root Test}

Though for, ARDL analysis, the test of stationarity may not be keen, to avoid any case of castigation, it is better the test is carried out for more reliable outcome. Table 1 presents the results of the unit root tests employing the $\mathrm{ADF}$ and PP tests. In both test, at level, all the variables are not stationary at $5 \%$ level of significant. However, when they are all differenced once, they became stationary at $1 \%$ level of significance. These results give use a good indication for further use. 
Table 1 Unit Root Tests

\begin{tabular}{|l|l|l|l|l|}
\hline & $\begin{array}{c}\text { Log of Broad Money } \\
\text { Supply (LM2) }\end{array}$ & $\begin{array}{c}\text { Log of Monetary } \\
\text { Policy Rate (LMR) }\end{array}$ & \multicolumn{1}{|c|}{$\begin{array}{c}\text { Log of Credit } \\
\text { Ratio (LCR) }\end{array}$} & $\begin{array}{c}\text { Log of Liquidity } \\
\text { Ratio (LLR) }\end{array}$ \\
\hline ADF & -2.4229 & -2.4374 & -0.9007 & -1.3741 \\
\hline Level & $-22.1749^{* * *}$ & $-17.2646^{* * *}$ & $-17.5474^{* * *}$ & $-17.5269^{* * *}$ \\
\hline $\mathbf{1}^{\text {st }}$ Difference & \multicolumn{5}{|l|}{} \\
\hline PP & -2.7541 & -1.0506 & -1.3482 \\
\hline Level & -2.6259 & $-17.6066^{* * *}$ & $-17.5314^{* * *}$ \\
\hline $\mathbf{1}^{\text {st }}$ Difference & $-22.2321^{* * *}$ & $-17.5245^{* * *}$ & \\
\hline$* * *$ indicates stationarity at 1\% significance level
\end{tabular}

Source: Author's own computations from E-Views 9

Table 2 presents result of pair-wise correlation matrix showing the relationship between two variables. Being most particular about broad money supply (M2) and each of other variables, the relationship between M2 and monetary policy rate (MR) shows averagely negative $(-0.52)$ meaning that there exists an inverse connection between them. Thus, an increase in MR will reduce M2 ceteris paribus. Same thing applies to liquidity ratio (LR) with negative sign (-0.69). These results of both of them are in line with theory.

Table 2 Pair-wise Correlation Matrix

\begin{tabular}{|l|l|l|l|l|}
\hline & LM2 & LMR & LCR & LLR \\
\hline LM2 & 1.0000 & -0.5183 & 0.1128 & -.0 .6875 \\
\hline LMR & -0.5183 & 1.0000 & 0.6506 & 0.6658 \\
\hline LCR & 0.1128 & 0.6506 & 1.0000 & 0.1928 \\
\hline LLR & -0.6875 & 0.6658 & 0.1928 & 1.0000 \\
\hline
\end{tabular}

Source: Author's own computations from E-Views 9

However, CR indicates an unexpected positive relationship with M2 and the value is so low, meaning that high CR will lead to high M2. This is not in tandem with theory.

Table 3 Lag Selection Order

\begin{tabular}{|c|c|c|c|c|c|c|}
\hline Lag & LogL & LR & FPE & AIC & SC & HQ \\
\hline 1 & 1757.920 & NA & $1.39 \mathrm{e}-10^{*}$ & $-11.34801^{*}$ & $-11.15378^{*}$ & $-11.27034^{*}$ \\
\hline 2 & 1764.992 & 13.77501 & $1.47 \mathrm{e}-10$ & -11.28985 & -10.90138 & -11.13450 \\
\hline 3 & 1787.389 & $43.04452^{*}$ & $1.41 \mathrm{e}-10$ & -11.33153 & -10.74883 & -11.09851 \\
\hline
\end{tabular}

* indicates lag order selected by the criterion

LR: sequential modified LR test statistic (each test at 5\% level)

FPE: Final prediction error

AIC: Akaike information criterion

SC: Schwarz information criterion

HQ: Hannan-Quinn information criterion

Table 3 show cases the lag selection order with five criteria. All the criteria selected lag 1 except LR which selected lag 3.

Tables 4 and 5 present the results of Johansen cointegration test using the Trace and Maximum Eigen Statistics. Using this test to diagnose the long run relationship between variables and bearing in mind that, if at least one cointegrating equation exists in the test statistics, it serves as an hallmark that one can go ahead to analyse using the error correction mechanism (ECM).

Table 4 Cointegration Rank (Trace Statistics) Results

\begin{tabular}{|c|c|c|c|c|}
\hline Hypothesised No of CE(s) & EigenValue & Trace Statistics & 0.05 CriticalValue & Prob** \\
\hline None $*$ & 0.636929 & 981.3100 & 47.85613 & 0.0001 \\
\hline At most $1 *$ & 0.599325 & 670.2709 & 29.79707 & 0.0001 \\
\hline At most $2 *$ & 0.495867 & 389.4870 & 15.49471 & 0.0001 \\
\hline At most $3 *$ & 0.442210 & 179.2180 & 3.841466 & 0.0000 \\
\hline \multicolumn{5}{|c|}{$\begin{array}{l}\text { Trace test indicates } 4 \text { cointegrating eqn(s) at the } 0.05 \text { level } \\
* \text { denotes rejection of the hypothesis at the } 0.05 \text { level } \\
* * \text { MacKinnon-Haug-Michelis (1999) p-values }\end{array}$} \\
\hline
\end{tabular}

Source: Author's own computations from E-Views 9.

From the result on Table 4 and 5, both Trace and Maximum Eigen statistics indicate 4 cointegrating equations at 5\% level of significance which is indicated by the Mackinnon-Haug-Michelis (1999) p-values as seen on the tables. Therefore, we can move to analyzing the short and long run impact analysis using the ECM. 
Table 5 Cointegration Rank (Maximum Eigen Statistics) Results

\begin{tabular}{|c|c|c|c|c|}
\hline Hypothesised No of CE(s) & Eigenvalue & Max.Eigen Statistics & 0.05 Critical Value & Prob** \\
\hline None * & 0.636929 & 311.0390 & 27.58434 & 0.0001 \\
\hline At most 1 * & 0.599325 & 280.7840 & 21.13162 & 0.0001 \\
\hline At most 2 * & 0.495867 & 210.2690 & 14.26460 & 0.0001 \\
\hline At most 3 & 0.442210 & 179.2180 & 3.841466 & 0.0000 \\
\hline
\end{tabular}

Max.Eigenvalue test indicates 4 cointegrating eqn(s) at the 0.05 level

* denotes rejection of the hypothesis at the 0.05 level

**MacKinnon-Haug-Michelis (1999) p-values

Source: Author's own computations from E-Views 9

Table 6 presents the long run analysis of the variables employed. Bearing in mind that DLM2 is our dependent variable, the monetary policy rate (MR) and liquidity ratio (LR) both show the correct negative sign and are both significant at $1 \%$ level of significance as their standard errors (0.046 and 0.059) and t-statistics (8.684 and -9.820) show. In the long run, an increase in MR and LR will reduce the M2 in the economy, meaning that a $1 \%$ increase in MR and LR, on the average, will lead to $0.40 \%$ and $0.58 \%$ reduction in M2. This is quite in line with our a priori expectation - in line with economic theory. However, CR could not give us the expected negative sign.

Table 6 Long Run Cointegrating Equation

\begin{tabular}{|c|r|c|c|}
\hline Variable & Coefficient & Std. Error & t-Statistic \\
\hline C & -0.0187 & - & - \\
\hline DLM2(-1) & 1.0000 & - & -8.6841 \\
\hline DLMR(-1) & -0.4003 & 0.0461 & 6.0562 \\
\hline DLCR(-1) & 0.1444 & 0.0239 & -9.8199 \\
\hline DLLR(-1) & -0.5824 & 0.0593 & - \\
\hline
\end{tabular}

Source: Author's own computations from E-Views 9

Table 7 presents the short run impact and error correction mechanism. All the three explanatory variables display the correct sign except MR. In the short run, CR and LR have negative impact on M2 but they are not significant even at $10 \%$ level. In the case of MR, it does not have the correct sign and it is not significant. The ECM coefficient shows the correct negative sign (-0.9117) and the figure is high, meaning that $91.2 \%$ of disequilibrium in M2 is corrected by MR, CR and LR within a month. More so the coefficient is significant at $1 \%$ level, hence the three variable have a strong power in adjusting broad money supply back to equilibrium.

Table 7 Cointegration (Short Run Coefficients and ECM)

\begin{tabular}{|c|c|c|c|}
\hline Variable & Coefficient & Std. Error & t-Statistic \\
\hline C & -0.0002 & 0.0031 & -0.0722 \\
\hline ECM & -0.9117 & 0.0569 & -16.0208 \\
\hline DLM2(-2) & -0.0713 & 0.0421 & -1.6921 \\
\hline DLMR(-2) & -0.0414 & 0.0410 & 1.0097 \\
\hline DLCR(-2) & -0.0432 & 0.0208 & -2.0732 \\
\hline DLLR(-2) & -0.0538 & 0.0544 & -0.9871 \\
\hline
\end{tabular}

Source: Author's own computations from E-Views 9

In order to adequately compare the three active monetary policy instruments and see the most effective in regulating money supply mobility, the study carried out a coefficient diagnostic test-Scaled Coefficient- which standardizes the coefficients and makes them ready for comparison.

Table 8 presents this result. It could be noticed that some of the variables are not showing the correct signs. We percolate Table 8 based on only the variables that show the expected sign to form another table, Table 9 for clarity in comparison. 
Table 8 Scaled Coefficients

\begin{tabular}{|c|c|c|c|}
\hline Variable & Coefficient & Standardised Coefficient & Elasticity atmean \\
\hline DLM2(-1) & -0.201698 & -0.201972 & -0.203393 \\
\hline DLM2(-2) & -0.090082 & -0.090241 & -0.091260 \\
\hline DLMR & 0.058831 & 0.066390 & -0.007048 \\
\hline DLMR(-1) & -0.011251 & -0.012696 & 0.001348 \\
\hline DLMR(-2) & -0.028494 & -0.032155 & 0.003414 \\
\hline DLCR & -0.009251 & -0.022394 & -0.002458 \\
\hline DLCR(-1) & 0.050134 & 0.121364 & 0.013322 \\
\hline DLCR(-2) & -0.022395 & -0.054215 & -0.005951 \\
\hline DLLR & -0.071807 & -0.067777 & 0.003412 \\
\hline DLLR(-1) & 0.160102 & 0.151117 & -0.007608 \\
\hline DLLR(-2) & -0.129851 & -0.122563 & 0.006171 \\
\hline C & 0.021643 & NA & 1.290053 \\
\hline
\end{tabular}

From Table 9, LR (-0.123 and -0.068) in both impulse and lag 2 periods appears to be the most effective impact on M2 in the short run. This is followed by the CR in both impulse and 2 lag periods. The much celebrated monetary policy rate (MR) comes third at 1 and 2 lag periods.

Table 9 Filtered Scaled Coefficients

\begin{tabular}{|c|c|c|c|}
\hline Variable & Coefficient & Standardised Coefficient & Elasticity atmean \\
\hline DLMR(-1) & -0.011251 & -0.012696 & 0.001348 \\
\hline DLMR(-2) & -0.028494 & -0.032155 & 0.003414 \\
\hline DLCR & -0.009251 & -0.022394 & -0.002458 \\
\hline DLCR(-2) & -0.022395 & -0.054215 & -0.005951 \\
\hline DLLR & -0.071807 & -0.067777 & 0.003412 \\
\hline DLLR(-2) & -0.129851 & -0.122563 & 0.006171 \\
\hline C & 0.021643 & NA & 1.290053 \\
\hline
\end{tabular}

The forecasted variance decomposition results are showcased on Table 10. In period 1, variation in M2 is explained solely by its own innovations. In period $2,74.7 \%$ of variations in M2 are explained by itself while the MR and LR explain 13.1 and $12.1 \%$, their explanations are quite significant as the standard error (S.E) show0.07 . However, in this same period 2, CR has no significant cause of variation in M2. From period 3 up to 10, the three explanatory variables continue to increase their contributions to variation in M2. MR increases from $16.9 \%$ through $21.7 \%$ which is the highest of all the three variables. LR follows with $12.2 \%$ in period 3 up to $16.8 \%$ in period 10 , and then CR with $1.6 \%$ to $4.4 \%$ between period 3 and 10 .

Table 10Variance Decomposition

\begin{tabular}{|c|c|c|c|c|c|}
\hline Period & S.E. & DLM2 & DLCR & DLLR & DLMR \\
\hline 1 & 0.053905 & 100.0000 & 0.000000 & 0.000000 & 0.000000 \\
\hline 2 & 0.065654 & 74.65585 & 0.090154 & 12.13696 & 13.11703 \\
\hline 3 & 0.074990 & 69.33975 & 1.613567 & 12.16628 & 16.88041 \\
\hline 4 & 0.083678 & 65.90763 & 2.406109 & 13.92962 & 17.75664 \\
\hline 5 & 0.091513 & 62.96706 & 3.017850 & 14.94044 & 19.07464 \\
\hline 6 & 0.098770 & 61.17442 & 3.421967 & 15.48258 & 19.92104 \\
\hline 7 & 0.105535 & 59.75835 & 3.742837 & 15.95850 & 20.54032 \\
\hline 8 & 0.111884 & 58.65541 & 3.999600 & 16.31307 & 21.03192 \\
\hline 9 & 0.117896 & 57.77742 & 4.203129 & 16.59577 & 21.42368 \\
\hline 10 & 0.123615 & 57.05654 & 4.369734 & 16.82826 & 21.74546 \\
\hline
\end{tabular}

The results of residual diagnostic test for no serial correlation and no conditional heteroskedasticity are presented on Table 10. For both Langrge Multiplier (LM) and White Chi-square employed, we accept the null hypothesis $\left(\mathrm{H}_{0}\right)$ of absence of both serial correlation and conditional heteroskedasticity since the p-values ( 0.2496 and 0.7317 ) indicate acceptance of the $\mathrm{H}_{0}$ at $5 \%$ level of significance.

\section{Table 11Residual Diagnostics}

\begin{tabular}{|l|l|l|r|}
\hline Test & Null Hypothesis & t-Statistic & Prob. \\
\hline Langrage Multiplier (LM) & No serial correlation & 1.401946 & 0.2496 \\
\hline White (CH-sq) & No conditional heteroskedesticity & 0.558453 & 0.7317 \\
\hline
\end{tabular}

In order to show that the model is consistent and reliable, stability check is carried out and the result is presented on Figure 3. From this figure, since the dots of the inverse roots of the AR polynomial are located within the circle, we conclude that the model satisfies the stability check condition and thus, our model is stable and reliable. 


\section{Inverse Roots of AR Characteristic Polynomial}

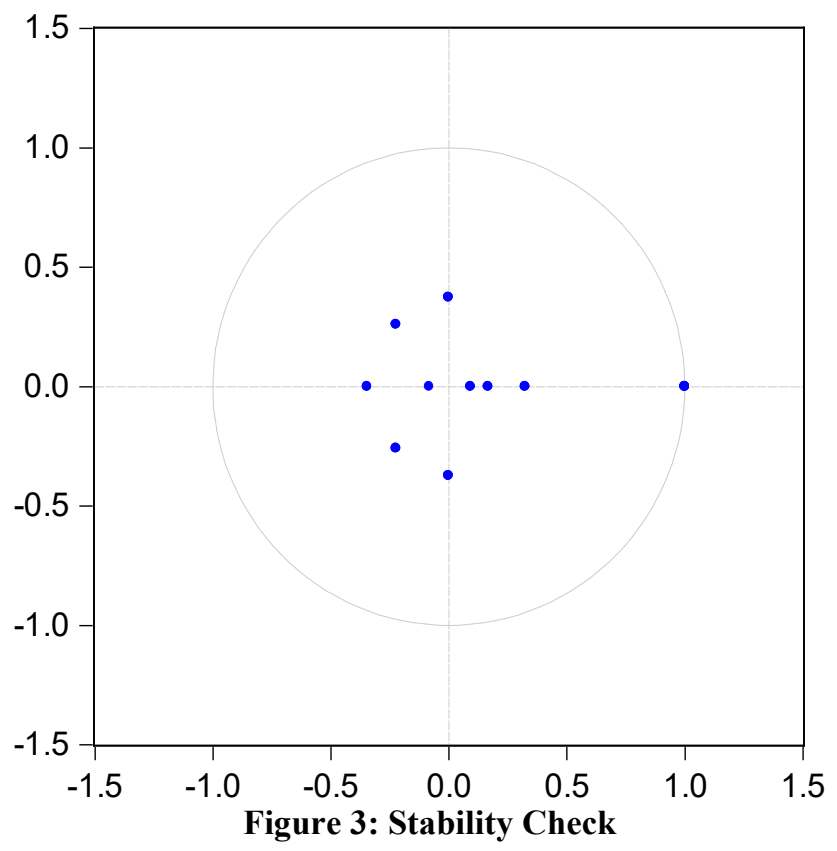

\section{Conclusion and Policy Implications and Recommendations}

The study researched on the impact of monetary policy instruments on broad money supply in Nigeria employing monthly time series data between 1993M1 and 2018M10. Data were sourced from the CBN online database accessed in January 2019. A vector error correction mechanism was employed to analyse the impact of monetary policy instruments on broad money supply and then Autoregressive Distributed Lag model were used to compare the variables. The monetary policy instruments considered in this work were monetary policy rate (MR), cash reserve ratio (CR) and liquidity ratio (LR) which were made the explanatory variables and broad money supply (M2), the dependent variable. Results from the study unveiled that, in the short run broad money supply responded negatively to changes in all the variables. All were not significant except cash ratio. In the long run, monetary policy rate and liquidity ratio had negative impact on broad money supply except cash ratio that had positive impact. All the impacts were significant. The monetary policy instruments employed had a high speed of adjusting broad money supply back to equilibrium. In comparing monetary policy instruments to regulating broad money, liquidity ratio happened to be the most effective and efficient instrument, followed by cash reserve and then monetary policy rate. However, MR had the highest ability to forecast money stock, followed by LR and then CR, and the abilities were felt even up to the eight month. The study, therefore recommends that the monetary authority should give most attention to LR in regulating money stock in Nigeria and mostly consider MR in forecasting the stock of money.

A number of policy implications regarding employing monetary policy to manage broad money supply. Firstly in the short run, cash reserve ratio is the best monetary policy instrument to control money supply since it was the only significant instruments. Secondly, for long run money supply control, liquidity ratio and then monetary policy rate would do great work. Thus, monetary authority in Nigeria should better employ these two instruments for long run management of money stock. However, liquidity ratio is the best single variable to effectively control broad money supply.

\section{Reference}

Abakpa1 A., Purokayo S., Asaph P. (2018). Analysis of the Determinants of Money Supply in Nigeria (19812015). International Journal of Scientific Research http://journalijsr.com/ Vol. III, Issue 2, 2018

Ali M. M. and Islam A. M. (2010). Money Supply Function for Bangladesh: An Empirical Analysis. AIUB BUS ECON Working Paper series. Vol. 10 No. 2010-01. http:/orp.aiub.edu/abewps-2010.

Bakare, A.S. (2011).An Empirical Study of the Determinants of Money Supply Growth and its Effect on Inflation Rate in Nigeria: Journal if Research in International Business and Management.Vol.1 (5).ISSN:2251-0028.

Cagan, P (1969) "Determination and Effects of Change in Stock of Money 1875/1960, New York: National Bureau of Economic Research.

CBN (2012). Understanding Monetary Policy Series No 3. Central Bank of Nigeria Monetary Policy Framework. 
CBN (2014). "Effects of Monetary Policy on the Real Economy of Nigeria": A Disaggregated Analysis. Occassional Paper 54 November 2014.

Central Bank of Nigeria (2005-2016). "Conduct of Monetary Policy in Nigeria". Different series.

Central Bank of Nigeria (2010-2016). Statistical bulletin, Online edition. www.cenbank.org.

Central Bank of Nigeria (2011): "Understanding Monetary Policy Series”. Series No. 3, March 2011.

Central Bank of Nigeria (2013). "Annual Report. www.cenbank.org.

Friedman, M. (2006). "Tradeoffs in Monetary Policy”. Paper prepared for David Laidler's Festschrift.

Friedman, M., and Schwartz, A. (1963a). "A monetary history of the United States, 1867-1960." Chicago: University of Chicago Press, 1963a.

James Meigs and William Wolman (1971). Central and the Money Supply. Economic Research: Federal Reserve Bank of St. Louis.

Meltzer, A. H. (1959). The Behaviour of the French Money Supply: 1938-54. Journal of Political Economy, University of Chicago Press, Vol. 67

Meltzer, A. H. (1995). Monetary, Credit and (Other) Transmission Processes: A Monetarist Perspective. The Journal of Economic Perspectives, Vol. 9, Issue 4, (Autumn 1995), pp 49-72.

Mishkin, F. (1995). "Symposium on the Monetary Transmission Mechanism". Journal of Economic Perspectives, 9(Fall):3 - 10 .

Mishkin, F. (2007). The Economics of Money, Banking, and Financial Markets. $8^{\text {th }}$ Edition. Pearson Education International, USA.

Mobolaji, H. and Oluwatoyin, O. (2012). "Financial Development and Human Capital in South Africa: A TimeSeries Approach". Macrothink Institute. Research in Applied Economics ISSN 1948-5433 2012, Vol. 4, No. 3.

Nkoro E. and Uko A. K. (2016). Autoregressive Distributed Lag (ARDL) cointegration technique: application and interpretation. Journal of Statistical and Econometric Methods, SCIENPRESS Ltd, vol. 5(4), pages 1-3.

Soludo, C.C. (2008). "Issues on the Level of Interest Rates in Nigeria". Extracted from http://www.cenbank.org/OUT/SPEECHES/2008/GOVADD30-6-08.PDF.

Tobin, J. (1965). Money and Economic Growth, "Econometrica, 33, 671 - 84.

Onuba I. (2019). CBN Retains Monetary Policy Rates at 14\%. Punch News Published on January 22, 2019. 